\title{
Personality Traits, Organizational Climate, Leadership Style and Job Satisfaction of Selected Government Employees in Aurora Zamboangadel Sur: A Correlational Study
}

\author{
${ }^{1}$ Anabelie V. Valdez, ${ }^{2}$ Rico J. Villa \\ ${ }^{1}$ Mindanao State University, Marawi City \\ ${ }^{2}$ Zamboangadel Sur, Provincial Government College
}

\begin{abstract}
The study investigates the Personality Traits, Organizational Climate, Leadership Style and Job Satisfaction of Selected Government Employees in Aurora Zamboangadel Sur and determined the extent relationship among the investigated variables. Descriptive correlational study design was used using survey questionnaires. The respondents were randomly and purposively selected based on their willingness and availability. Findings revealed that most of them are young leaders, female, graduate degree, below ten years of experience and with average salary rate. Results also showed that the selected personal profile of the respondents are significantly correlated to their personality traits, organizational climate, leadership styles and job satisfaction. Moreover, their personality traits influence significantly to their leadership styles and the leadership styles are significantly affects the organizational climate and job satisfaction of the respondents and the other employees. Thus, it is concluded that every leader should evaluate their personality traits and leadership styles and make some precautions and or changes when it comes to maintain favorable organizational climate, working environment and job satisfaction of all employees.
\end{abstract}

Keywords: personality traits, organizational climate, leadership style, job satisfaction, aurora zambonagadelsur

\section{Rationale}

In any organization, Personality Traits, Organizational Climate, Leadership Style and Job Satisfactionare vital and equally important. Personality traits are a unique identity of individual person. According to Gibson (2012), personality traits contribute to human behavior that has been formed by inheritance that is influence by environmental factors such as social and cultural context. Kreitner (2010) defined personality as relative to enduring individual traits and dispositions and identity.

Leadership style and organizational climate should be favorable, conducive and friendly to the working environment of the workers or employees in an organization. It is a global challenge to improve the organizational effectiveness of any organization or institution. Castro, M., \& Martins, N. (2010) pointed out that organizational climate should give development to the human resources to be more competitive with the ever changing environment by providing a dynamic organizational resources.

Organizational Climate and job satisfaction can be determined through individual personality traits and leadership styles. Felfe and Schyn's (2010) mentioned that personality influence the leaders' leadership style and organizational climate. Based on the multidimensional model of leadership, personal characteristics of a leader attribute to his or her leadership style and the leadership style has direct influence to the organizational climate.

Empowerment, motivation, and professional growth positively contribute to the productivity of any organization particularly among schools or academic institutions. Leaders should initiate and support for the development of employees or workers as capital of excellence and competitiveness (Kasekende, 2016).

On the other hand, job satisfaction often determined by the emotional response to the workers work situation and this is also related to individual attitudes and upbringing. Luthans (2011) said that attitude and job 
satisfaction is interrelated and relative while job satisfaction is attributed by cognitive and behavior of individual person (Judge, T. A., Bono, J. E., Llies, R., \& Gerhardt, M. W., 2002).

\section{Methods}

This study investigates the Personality Traits, Organizational Climate, Leadership Style and Job Satisfaction of Selected Government Employees in Aurora ZamboangadelSur specifically aimed to:

a. Identify the profile of the respondents

b. Assess the personality traits, organizational climate, management and leadership style and job satisfaction of the randomly select government employees in Aurora Zamboangadel Sur.

c. Determine the relationships of respondents profile, personality traits, organizational climate, and leadership style and job satisfaction of employees.

\subsection{Research Design}

This study made used of descriptive-correlational research using survey questionnaires. Patterned from the survey model of Karasar (1999) descriptive-correlational approach was used to determine and described the relationships and effects of the variables investigated in the study. In the frame of this model, the Personality Traits, Organizational Climate, Leadership Style and Job Satisfaction of Selected Government Employees in Aurora Zamboanga Del Sur were described quantitatively. Correlational relationship was established using correlational statistics.

\subsection{Research Locale and Respondents}

This study participated by twenty six (26) randomly selected government employees of Aurora Zamboangadel Sur using purposive and convenient sampling.

\subsection{Research Instrument and Procedures}

The instruments used in collecting data were the survey questionnaires adapted from other researches across the globe. The survey questionnaire was validated in the Philippine setting considering the Filipino context. The survey questionnaire composed of open-ended questions and five point Likert type.

\subsection{Data Analysis}

Datum collected from survey questionnaires was analyzed using the Statistical Package for Social Science (SPSS) software. Specifically, statistical analysis includes descriptive statistics such as frequency, percentage, and weighted mean. This was used to present databout the personal point of view and selfassessment of the respondents on the different attributes they possessed. Correlation (r-statistic) test was applied to determine the relationship between the variables investigated.

\section{Results and Discussion}

Table 1

Profile of the Respondents

\begin{tabular}{|c|c|c|c|}
\hline Profile & Range/Determinants & $\mathbf{F}$ & $\%$ \\
\hline \multirow[t]{3}{*}{ Age } & 25 below & 15 & 57.692 \\
\hline & $26-35$ & 5 & 19.231 \\
\hline & $36-45$ & 6 & 23.077 \\
\hline \multirow[t]{2}{*}{ Gender } & male & 7 & 26.923 \\
\hline & female & 19 & 73.077 \\
\hline \multirow[t]{2}{*}{ Marital Status } & single & 16 & 61.538 \\
\hline & married & 11 & 42.308 \\
\hline \multirow{3}{*}{$\begin{array}{l}\text { Educational } \\
\text { Attainment }\end{array}$} & Undergrad Degree & 6 & 23.077 \\
\hline & Diploma Courses & 2 & 7.6923 \\
\hline & Graduate degree & 18 & 69.231 \\
\hline \multirow{2}{*}{$\begin{array}{l}\text { Length of } \\
\text { Experience }\end{array}$} & $0-10 y r s$ & 18 & 69.231 \\
\hline & $11.00-20$ & 8 & 30.769 \\
\hline
\end{tabular}




\begin{tabular}{|c|c|c|r|}
\hline \multirow{3}{*}{ Salary } & below 5k & 6 & 23.077 \\
\cline { 2 - 4 } & $5-8 \mathrm{k}$ & 0 & 0 \\
\cline { 2 - 4 } & $8-12 \mathrm{k}$ & 10 & 38.462 \\
\cline { 2 - 4 } & $12 \mathrm{k}$ above & 10 & 38.462 \\
\hline
\end{tabular}

Table 1 presents the selected profile of the respondents. As shown in the table many (58\%) of them are young (below 25 years old); female (73\%); single (62\%); graduate degree $(69 \%)$; below ten years of experience (69\%); and with monthly salary $8,000.00-12,000.00$ and above $(38 \%)$.

Table 2

Personality Traits of the Respondents

\begin{tabular}{|c|c|c|}
\hline Personality Traits & F & $\%$ \\
\hline L & 10 & 38.462 \\
\hline O & 3 & 11.538 \\
\hline G & 4 & 15.385 \\
\hline B & 9 & 34.615 \\
\hline
\end{tabular}

Table 2 shows the personality traits of the respondents which is describe in accordance of a certain animal behavior represented by letters. Each letter (L, O, G, and B) stands for a particular personality type. L stands for lion, $\mathrm{O}$ for otters, $\mathrm{G}$ for golden retrievers, and B for beavers. As shown in Table 2, mostly are inclined to a lion personality $(38.5 \%)$. Being a lion as leader they are usually the bosses at work. On the positive side Lions are very confident and self-reliant. However, they are influential, eccentric and love to seek new ventures and opportunities. This kind of personality is common among entrepreneurs in which in terms of pressure or tense situations, they takes command and becomes autocratic. On the other hand, they desire freedom, authority, variety, difficult assignments, and opportunity for advancement.

Second in rank is the beaver's personality (34.6\%). Beaver personality are erudite, provide quality control in the office, in any situation or field and demands for precision. They instruct with high standards and consistency. Their desire is to be right and maintain quality. Person with Beavers personality tend to work slowly to make sure they are accurate. They are good listeners, communicate details, and are usually diplomatic. In decision making they tend to avoids making decisions; needs lots of information before they will make a decision. They also avoid pressure or tense situations and can ignore deadlines.

Third is an employee that has golden retrievers' personality. This personality shows most loyalty, they can absorb the most emotional pain and punishment in a relationship and still stay committed. A person with golden retriever personality is a good listener to others, concerned and encouragers. In times of decision making, they act it more slowly, want input from others, and often yield to the input. When they are under pressure and tense, this kind of personality gives in to the opinions, ideas, and wishes of others. Often times are too tolerant.

Fourth are employees with likelihood of an otter's personality (11.5\%). Otters are a personality trait that is adventurous, easy to be exited, and love to talk. They are good in motivating people, very loving, and encourager and spoken. Person that have otters personality are fashionable and socialites. In decision making they are intuitive and fast with communication styles that are enthusiastic and stimulating. However, when otter's personality is under pressure they will attack. They are also more concerned about popularity than about achieving tangible results yet they fast-paced and people oriented.

Table 3

Organizational Climate

\begin{tabular}{|l|l|l|l|}
\hline Organizational Climate & F & \% & Overall Mean \\
\hline Highly Satisfied & 20 & 76.92 & 19.885 \\
\hline Not Satisfied & 6 & 23.08 & 4.769 \\
\hline
\end{tabular}


Legend:

$$
\begin{aligned}
& \text { 20-25 = Highly Satisfied } \\
& 5-9=\text { Dissatisfied }
\end{aligned}
$$

$$
\begin{aligned}
& 15-19=\text { Satisfied } \\
& 1-4=\text { Highly Dissatisfied }
\end{aligned}
$$

Based on the date presented in Table 3, twenty (20) out of 26 respondents said that they are highly satisfied with their working environment in terms of their organizational climate, while six (6) of them said that they are satisfied.During survey, many of them said that they have high working experience, satisfied with the autonomy they experience. Furthermore, they have always formal relationship with their immediate supervisor but they are free to communicate with the other employee or staff. Similarly, they are also free to express their views and suggestions in decision making process, however, their views and suggestions are only considered sometimes.

In terms of recognition and competitiveness, they said that their organization/office gives due recognition to them particularly their immediate supervisor. They also said that the competition within their organization is just an average.For rewards and benefits, they always given monetary in which they were satisfied. However, sometimes promotion and incentives were also given.

Table 4

Perceived Management \&Leadership Style

\begin{tabular}{|l|c|c|}
\hline \multicolumn{1}{|c|}{ Management Style\& Leadership Style } & F & \% \\
\hline Autocratic & 1 & 3.846 \\
\hline Bureaucratic & 7 & 26.92 \\
\hline Democratic & 5 & 19.23 \\
\hline Laissez Fair & 0 & 0 \\
\hline Paternalistic & 6 & 23.08 \\
\hline Democratic \& Laissez fair & 1 & 3.846 \\
\hline Autocratic, Bureaucratic, Democratic, Laissez fair \&Paternalistic & 2 & 7.692 \\
\hline Democratic \&Paternalistic & 1 & 3.846 \\
\hline Bureaucratic, Democratic \&Paternalistic & 1 & 3.846 \\
\hline Autocratic. Democratic \&Paternalistic & 1 & 3.846 \\
\hline Autocratic, Laissez fair \&Paternalistic & 1 & 3.846 \\
\hline
\end{tabular}

Table 4 depicts the different preferred management and leadership styles of the respondents. As shown in the data, many $(26.92 \%)$ practiced bureaucratic style. These results implied that the respondents are a leader that work by book following the rules rigorously and ensure that their staff should follow the procedures precisely.

There were also $23.08 \%$ of the respondents practice paternalistic styles. This implies that they act more likely as parent than being a boss. In this style of leadership, the authority is in the hand of individual and that individual cares more about employees than outcomes and profits. They believed that employees are the heart of the organization and it holds higher priority on employees' satisfaction. This kind of leader is practicing the top-down and bottom-up communication.

Other respondents $(19.23 \%)$ preferred democratic style of leadership. Being a democratic leader they allow the employees to voice out their opinions. They prefer to have an open door policy in the organization to ensure that the management and the employees communicate openly and freely with each other.

Other few of the respondents are practicing autocratic and or a combination of different management and leadership styles and none of them practiced laissez fair leadership style. In the autocratic leadership, the head has the complete authority and no one else can question it. This kind of leadership will cause dissatisfaction of employees and limit employees' creative space. The leader will just consider the employees as replaceable resource and not the core of the organization. 
Table 4.1

Leadership Style Tendency

\begin{tabular}{|l|r|r|r|}
\hline \multicolumn{1}{|c|}{ Tendency of Leadership style } & F & \% & Mean \\
\hline Facilitate & 0 & 0 & 0 \\
\hline Delegate & 2 & 7.692 & 0.077 \\
\hline Coach & 7 & 26.92 & 0.269 \\
\hline Direct & 4 & 15.38 & 0.154 \\
\hline Facilitate, Delegate, Coach and Direct & 4 & 15.38 & 0.154 \\
\hline Facilitate and Coach & 1 & 3.846 & 0.038 \\
\hline Coach and Direct & 1 & 3.846 & 0.038 \\
\hline Delegate and Direct & 2 & 7.692 & 0.077 \\
\hline Facilitate, Coach and Direct & 1 & 3.846 & 0.038 \\
\hline Facilitate, Coach and Delegate & 1 & 3.846 & 0.038 \\
\hline Facilitate and Delegate & 2 & 7.692 & 0.077 \\
\hline NO RESPONSE & 1 & 3.846 & 0.038 \\
\hline
\end{tabular}

Table 4.1 supports the result in Table 4 regarding the management and leadership style of the respondents. This leadership style tendency assessed how the respondents approach their employees and colleagues. As shown in the table, many $(26.92 \%)$ of them practiced coaching followed by directing and a combination of facilitating, delegating, coaching and directing. Couching leaders are trying to motivate employees or people to make decisions, sell in their own ability to do the job, praise the good work, and provide feedback on what they are doing. Directing leader provide detailed instructions, give specific goals and objectives and frequently check the workers to keep them on track. Facilitating leader on the other hand involve the employee/workers in making decisions, make them feel free to ask questions and discuss important concerns, hold frequent meetings and listen to the employees issues and concerns without criticizing and judging. Similarly, a delegating leader delegate broad responsibilities to the employees/workers and expect them to handle the details.

Table 5

Summary on Job Satisfaction as Perceived by the Employees

\begin{tabular}{|l|l|r|r|}
\hline \multicolumn{1}{c|}{ Opinion about their job } & \multicolumn{1}{c|}{ F } & \multicolumn{1}{c|}{$\boldsymbol{\%}$} & \multicolumn{1}{c|}{ Mean } \\
\hline Great Job & 18 & 69.23 & 0.69 \\
\hline Good Job & 2 & 7.69 & 0.08 \\
\hline Ok Job & 2 & 7.69 & 0.08 \\
\hline Bad Job & 2 & 7.69 & 0.08 \\
\hline Depressing Job & 2 & 7.69 & 0.08 \\
\hline
\end{tabular}

Table 5 is the summary of respondents' opinion and perceptions about their job. As shown in the table many $(69.23 \%)$ claimed that they have a great job and they are satisfied with their job. Others claimed that they have only good job and ok job (7.69\%). While $7.69 \%$ claimed that they have a bad and depressing job.

Table 6

Relationship between Respondents Profile and Personality Traits, Organizational Climate,

Leadership Style and Job Satisfaction

\begin{tabular}{|l|l|r|r|r|r|r|}
\hline \multicolumn{1}{|c|}{ Profile } & & $\begin{array}{c}\text { Job } \\
\text { Satisfaction }\end{array}$ & $\begin{array}{c}\text { Personality } \\
\text { Traits }\end{array}$ & $\begin{array}{c}\text { Organizational } \\
\text { Climate }\end{array}$ & $\begin{array}{c}\text { Style } \\
\text { Tendency }\end{array}$ & $\begin{array}{c}\text { Leadership } \\
\text { Style }\end{array}$ \\
\hline \multirow{2}{*}{ Age } & R & $.882^{* *}$ & $.857^{* *}$ & $.889^{* * *}$ & $.910^{* * *}$ & $.927^{* * *}$ \\
\cline { 2 - 7 } & Sig. & .000 & .000 & .000 & .000 & .000 \\
\hline \multirow{2}{*}{ Gender } & R & .356 & $.678^{* * *}$ & .332 & $.604^{* * *}$ & $.580^{* * *}$ \\
\cline { 2 - 7 } & Sig & .074 & .000 & .097 & .001 & .002 \\
\hline Marital Status & R & $.743^{* *}$ & $.870^{* * *}$ & $.693^{* * *}$ & $.811^{* * *}$ & $.854^{* * *}$ \\
\hline
\end{tabular}




\begin{tabular}{|l|l|r|r|r|r|r|}
\hline & Sig. & .000 & .000 & .000 & .000 & .000 \\
\hline \multirow{3}{*}{ Education } & $\mathrm{R}$ & $.410^{*}$ & $.781^{* *}$ & .383 & $.675^{* *}$ & $.660^{* * *}$ \\
\cline { 2 - 7 } & Sig. & .037 & .000 & .054 & .000 & .000 \\
\hline \multirow{3}{*}{ Salary } & $\mathrm{R}$ & $.646^{* *}$ & $.885^{* *}$ & $.602^{* *}$ & $.814^{* *}$ & $.833^{* *}$ \\
\cline { 2 - 7 } & Sig. & .000 & .000 & .001 & .000 & .000 \\
\hline \multirow{2}{*}{ Experience } & $\mathrm{R}$ & $.881^{* *}$ & $.784^{* *}$ & $.822^{* *}$ & $.826^{* *}$ & $.896^{* *}$ \\
\cline { 2 - 7 } & Sig. & .000 & .000 & .000 & .000 & .000 \\
\hline
\end{tabular}

Table 6shows the relationship of the profile of the respondents and their personality traits, perceived organizational climate, leadership style and job satisfaction. As shown in the table only gender shows no relationship to job satisfaction. This implies that sex does not matter with regards to job satisfaction. This means that both male and female are aiming to be satisfied with their job. On the other hand gender and education also shows no relation to organizational climate. This means that organizational climate is an independent entity and does not affect with the professional qualification and sex of the leaders. The respondents' profiles that are highly correlated to personality traits, organizational climate, leadership styles and job satisfaction at 0.01 and or 0.05 level of significance are age, marital status, salary and experience. Gender is highly correlated to personality traits, style tendency and leadership style. Education on the other hand is highly correlated to job satisfaction, personality traits, style tendency and job satisfaction. Study conducted by Ulucan (2017) pointed out that job satisfaction and work-family conflicts exhibited by physical education teachers are not significantly related each other. This means that the entities are independent and may not have direct effects against each other.

Table 7

Relationship among Leadership Style and Personality Traits, Organizational Climate and Job Satisfaction

\begin{tabular}{|c|c|c|c|c|c|c|}
\hline \multicolumn{2}{|c|}{ Variables Correlated } & \multirow{2}{*}{$\begin{array}{c}\text { Job } \\
\text { satisfaction }\end{array}$} & \multirow{2}{*}{$\begin{array}{r}\begin{array}{l}\text { Personality } \\
\text { traits }\end{array} \\
.691^{* *}\end{array}$} & \multirow{2}{*}{$\begin{array}{c}\begin{array}{c}\text { Organizational } \\
\text { climate }\end{array} \\
.933^{* *}\end{array}$} & \multirow{2}{*}{$\begin{array}{r}\begin{array}{c}\text { Style } \\
\text { Tendency }\end{array} \\
.908^{* *}\end{array}$} & \multirow{2}{*}{$\begin{array}{l}\begin{array}{l}\text { Leadershi } \\
\text { p style }\end{array} \\
.914^{* * *}\end{array}$} \\
\hline Job satisfaction & $\mathrm{r}$ & & & & & \\
\hline & Sig. & & .000 & .000 & .000 & .000 \\
\hline \multirow[t]{2}{*}{ Personality traits } & $\mathrm{r}$ & $.691^{* *}$ & & $.644^{* * *}$ & $.880^{* *}$ & $.893^{* *}$ \\
\hline & Sig. & .000 & & .000 & .000 & .000 \\
\hline \multirow[t]{2}{*}{ Organizational climate } & $\mathrm{r}$ & $.933^{* * *}$ & $.644^{* *}$ & & $.840^{* * *}$ & $.839^{* * *}$ \\
\hline & Sig. & .000 & .000 & & .000 & .000 \\
\hline \multirow[t]{2}{*}{ Style tendency } & $\mathrm{r}$ & $.908^{* * *}$ & $.880^{* *}$ & $.840^{* *}$ & & $.974^{* *}$ \\
\hline & Sig. & .000 & .000 & .000 & & .000 \\
\hline \multirow[t]{2}{*}{ Leadership style } & $\mathrm{r}$ & $.914^{* * *}$ & $.893^{* *}$ & $.839^{* *}$ & $.974^{* *}$ & \\
\hline & Sig. & .000 & .000 & .000 & .000 & \\
\hline
\end{tabular}

Table 7 presents the extent relationship of the personality traits, organizational climate, and leadership style and job satisfaction as perceived and practiced by the respondents. As shown, personality traits, organizational climate, leadership style and job satisfaction are significantly highly correlated to each other. This implies that one variable directly affect each other and they are dependent with each other. Personality traits of the leaders has significant bearing on the organizational climate, leadership style and job satisfaction. These also hold true to other variables wherein the organizational climate, leadership style and job satisfaction are having significant relationship and it directly influence with each other.

Study of Yuxin Liu \&Jianwei Zhang (2010) had similar results to this study. Their findings revealed that educational level, position and length of time working had significant main effects on organizationalclimate; specialty, enterprise character and enterprise size also had significant main effects on organizationalclimate; while organizational climate had significant main effects on human resources management effectiveness suchas turnover intention, job satisfaction and work efficacy. Furthermore, organizational climate also had significant main effectson organization effectiveness like staff members' organization commitment and collective identity.

Similarly, results on the study conducted by Hassan, Asad, and Hoshino (2016) also confirmed the findings of this study stating that leadership styles are associated with personality types and that personality 
impacted the leadership style of the leaders. Thus, this relationship should be considered in determining the effectiveness of leadership.Bono, J. E., \& Judge, T. A. (2002) study also revealed that personality traits have significant bearing on the leadership styles of the leaders.Furthermore, leadership styles have a positive correlation to the employee job satisfaction (Afshinpour, 2014). Research findings of Loganathan (2013) also confirmed that leadership styles and job satisfaction is significantly correlated.

\section{Conclusion}

The current study concluded that the respondent's personal profiles are more like similar and they have common personality traits and leadership styles. The respondents also perceived that they have a great job and good working environment. In the extent of relationship among variables, the personal profile of the respondents is significantly related to their Personality Traits, Organizational Climate, Leadership Style and Job Satisfaction. Moreover, leadership styles are influence by the personality trait of a person and in the same manner, leadership styles will influence and significantly affects the organizational climate and job satisfaction of the workers. In fact Ali, A. Y. S., Sidow, M. A. \&Guleid, H. S. (2013) study also concluded that different countries show different leadership styles and do not have the same impact on job satisfaction. However, leadership styles are more likely to provide greater commitment and job satisfaction of the employees.

\section{References}

[1] Afshinpour, S. (2014).Leadership Styles and Employee Satisfaction: A Correlation Study. International Letters of Social and Humanistic Sciences Online: 2014-05-04 ISSN: 2300-2697, Vol. 27, pp 156-169doi:10.18052/www.scipress.com/ILSHS.27.156C 2014 SciPress Ltd., Switzerland.

[2] Ali, A. Y. S., Sidow, M. A. \&Guleid, H. S. (2013) Leadership styles and job satisfaction: empirical evidence from Mogadishu universities. European Journal of Management Sciences and Economics

[3] Bono, J. E., \& Judge, T. A. (2002). Personality and Leadership: A Qualitative and Quantitative Review. Journal of Applied Psychology, 87(4), 765-780.

[4] Castro, M., \& Martins, N. (2010). The relationship between organisational climate and employee satisfaction in a South African information and technology organisation.SA Journal of Industrial sychology/SA TydskrifvirBedryfsielkunde, 36(1), Art.\#800, 9 pages. DOI: 10.4102/sajip.v36i1.800

[5] Felfe, J., \&Schyns, B. (2010). Follower's Personality and the Perception of Transformational Leadership: Further Evidencefor the Similarity Hypothesis. British Journal of Management, 21, 393-410.

[6] Gibson, James L., John M. Ivancevich,Donelly, and Konopaske (2012).Organizational Behavior, Structure, Processes.Fourteenth Edition. New York: McGraw Hill.

[7] Hassan, H., Asad, S., Hoshino, Y. (2016).Determinants of Leadership Style in Big Five Personality Dimensions. Universal Journal of Management 4(4): 161-179, 2016 http://www.hrpub.orgDOI: 10.13189/ujm.2016.040402

[8] Jex, Steve M. (2002). Organizational Psychology A Scientist-Practitioner Approach. New York: John Wiley \&Son Inc,

[9] Judge, T. A., Bono, J. E., Llies, R., \& Gerhardt, M. W. (2002). Personality and Leadership: A Qualitative and Quantitative review. Journal of Applied Psychology, 87, 765-780. http://dx.doi.org/10.1037/0021-9010.87.4.765

[10] Kasekende, Francis (2016). "Linking teacher competences to organizational citizenship behaviour" The International Journal of Educational Management; Bradford Vol. 30, Iss. 2, (2016): 252-270. Emerald Group Publishing Limited

[11] Kreitner, R. and Angelo, K. (2010).Organizational Behavior, Seventh Edition, New York: McGraw Hill

[12] Loganathan, R. (April 2013). The Influence Of Leadership Styles On Job Satisfaction At ACellulose Pulp Mill In Kwazulu-Natal: A Case Study. Dissertation submitted in fulfillment of the requirements for the degree ofMasters in Technology: Business Administrationin the faculty of Management Sciences at the Durban University of Technology

[13] Luthans, Fred (2011). Organizational Behavior AnEvidence Based Approach. New York: McGraw Hill Irwin,

[14] Ulucan, H. (2017). Relationship between Job Satisfaction Levels and Work-Family Conflicts of Physical Education Teachers.Journal of Education and Learning; Vol. 6, No. 3; 2017ISSN 1927-5250 E-ISSN 1927-5269Published by Canadian Center of Science and Education 312

[15] Yuxin L.\&Jianwei Z. (2010).Organizational Climate and its Effects on Organizational Variables: An Empirical Study www.ccsenet.org/ijps International Journal of Psychological Studies Vol. 2, No. 2; December 2010. 